\title{
Production organization capacity of ethnic minorities in northwestern region of Vietnam
}

\author{
Thu Trang $\mathrm{Vu}^{1 *}$; Dung $\mathrm{Vu}^{2}$, and Thi Mai Lan Nguyen ${ }^{3}$, \\ ${ }^{1}$ Graduate Academy of Social Sciences, 477 Nguyen Trai street, Thanh Xuan district, Hanoi, \\ Vietnam. 10000 \\ ${ }^{2}$ Institute of Psychology, 37 Kim Ma Thuong Street, Ba Đinh district, Hanoi, Vietnam. 10000. \\ ${ }^{3}$ Graduate Academy of Social Sciences, 477 Nguyen Trai street, Thanh Xuan district, Hanoi, \\ Vietnam. 10000
}

\begin{abstract}
Survey results of 1,452 people representing families of 6 ethnic minorities in 11 communes of 7 districts in 7 provinces in the Northwest region shows that the production organization capacity of the ethnic minorities surveyed has changed, but still remains many limitations. The change in production capacity of ethnic minorities is reflected in the fact that the majority of families have produced in a new way (know how to use some machines, use new plant varieties and breeds, apply chemical fertilizers, use pesticides, and some agricultural products produced for sale).The limitations of the production organization capacity of ethnic minority families are shifting cultivation, dibbling, rudimentary production tools, low labor productivity, production by small-scale, autarky, shifting cultivation of wandering hilltribes). If comparing between traditional production method and new production method, the traditional production method is still more prevalent. One of the main causes of this situation is that ethnic minorities live in mountainous areas with difficult transportation, so the main cultivation method is shifting cultivation. The application of machines in production faces many difficulties.
\end{abstract}

\section{Introduction}

The Northwest is a territory in the North of Vietnam. The Northwest includes the provinces of Hoa Binh, Son La, Dien Bien, Lai Chau and a part of the territory of Lao Cai, Yen Bai and Ha Giang. The Northwest has complex terrain and rugged mountains. The Northwest is a land of rich potentials for minerals, forestry, agricultural crops, and tourism. The Northwest has a direct influence of the ecological environment on the entire midland and delta region. The Northwest is the long-standing residence area of more than 20 ethnic groups belonging to 7 different language groups (Tay - Thai; Ka Dai; Mon - Khmer; H'mong - Dao; Han; Tibetan - Burmese; Vietnamese - Muong).According to the 2009 Population and Housing Census, there are currently 50 ethnic groups living in the Northwest, including 49 ethnic minorities. Ethnic minorities with the largest population are the Tay, Thai, Muong, H'mong, Dao, Kho mu, Giay and Ha Nhi [14]. Each ethnic group

* Corresponding author: trangvuthu90@gmail.com 
has different origin and history, its own cultural identity and psychological characteristics. In recent years, with the attention of the Party and State, the Northwest has been making great changes, the lives of ethnic groups have been improved, and the infrastructure has been improved.

However, due to many objective and subjective reasons, the Northwest still faces many difficulties and challenges. The production capacity of ethnic minorities is still limited, the economy of a part of ethnic minority families is still difficult. This article focuses on the analysis of Northwestern ethnic minorities' production capacity in the current conditions of Vietnam's market economy development and international integration.

Ethnic minorities and the production capacity of ethnic minorities have attracted great interest from many researchers, including these following typical studies: Altay A. Manço (1996) studied on identifying local integration policies for ethnic minorities through social development activities at the local level and public services. The author analyzed the characteristics, needs and skills of ethnic minorities via their communication and integration with local political organizations [15]. Taner Oc and Steven Tiesdell (1999) performed a research assessment on business support for ethnic minorities in city challenge areas in the UK through initiatives of training and employment [16]. Peter S. Li (2004) studied on social capital and economic outcomes for immigrants and ethnic minorities by analyzing forms of social capital affecting the economic well-being of immigrants and ethnic minorities. The author argues that individuals and social groups can use social capital, but social capital cannot replace other forms of capital with these social groups [17]. A. R. J. Dainty, B. M. Bagilhole, K. H. Ansari, and J. Jackson (2004) studied on ethnic minority women of the construction industry in the UK. The research results showed that women and ethnic minority employees face both challenges and barriers on discrimination as well as gender inequality in their professional activities [18].

The Regional Technical Assistance (RETA) of the Asian Development Bank (ADB) on Capacity Building for Indigenous Peoples, Ethnic Minority Issues and Poverty Alleviation (RETA 5953) piloted in four developing member countries (DMCs) in the region, namely Cambodia, Indonesia, the Philippines and Vietnam (2004). This project aims to strengthen national capacity to combat poverty and enhance the quality of ADB interventions as they affect indigenous peoples. The study also analyzes the situation of the ethnic majority group (Kinh) and 53 ethnic minority groups in Vietnam. Some ethnic minority groups have a higher population and are skilled in practicing wet rice cultivation (such as the Tay, Thai and Muong people) living in lowlands and valleys along rivers and streams, where they can access water and traffic. They can cultivate both wet rice and upland fields. In addition, most of the ethnic minority population living in remote or mountainous areas mainly cultivate upland fields. The study also analyzes Vietnam's reform and economic policies. In Vietnam, all ethnic groups are equal. Since the 1960s, new economic zones and resettlement have been established. In the mountainous areas, they are organized as stateowned agro-forestry enterprises or as new economic villages. In 1968, Vietnam launched a fixed farming campaign to replace shifting cultivation. Sedentary farming has been considered an important policy for the economic development of ethnic minorities in Vietnam [19].

Robert M Goodman has investigated the capacity of community-based initiatives in racial and ethnic communities. First, community capacity is identified and briefly contrasted with social capital. Then, the research methodology is described from which capacity building is derived. The study found that some of the competencies of communitybased initiatives are important in distinguishing highly successful initiatives from those that have much difficulty realizing their goals. The study concluded that developing high levels of community capacity, where it produce the most strategic advantage is a promising path to minimize antagonistic social factors. Community participation in public health 
promotion activities is a basic discipline for public health and the ability to implement successful community initiatives [20]. David Deakins, Madhavi Majmudar \& Andrew Paddison (2010) studied on developing successful strategies for ethnic minorities in business. The study was conducted in Scotland including 43 qualitative interviews with ethnic minority business owners and entrepreneurs from the Strathclyde region. Research results showed that businesses are successful thanks to creativity [21].

Authors Vu Hoang Giang, Nguyen Tam, Gibson, John Giles, John Hinsdale, Pham Lan Hung, Kozel, Valerie Lanjouw, Peter Marra, Marleen Ngoc, Vu Van Phuong, Nguyen Thi Schuler, Paul Thang, Nguyen Thanh, Hoang Xuan (2012) under the World Bank's funding, assessed Vietnam's poverty in 2012: well begun, not yet done - Vietnam's remarkable progress on poverty reduction and the emerging challenges a good start, not yet implemented - Vietnam's remarkable progress on poverty reduction and emerging challenges. This study looked at the lives of poor men, women and children, showing the constraints and opportunities they face when escaping from poverty [22]. Katsushi S. Imai, Raghav Gaiha \& Woojin Kang (2011) have studied on poverty, inequality and ethnic minorities in Vietnam. The study results show that ethnic minorities are not only poorer but also more vulnerable than the Kinh and Hoa people. They are also more likely to experience different shocks. Factors such as household composition (eg, dependency burden), education, land holdings and location are important determinants of expenditure and poverty of ethnic minorities [23]. Tran Quang Tuyen (2015) studied on socio-economic determinants of household income among ethnic minorities in Northwestern mountainous region - the poorest region in Vietnam. The findings showed that the vast majority of the households in the sample rely heavily on agricultural activities [24]. Nguyen Viet Cuong and Phung Duc Tung (2015) analyzed the program "Socio-economic development for communes" facing the greatest difficulties in ethnic minority and mountainous areas in 2006. The article showed that this program has a positive impact on some important outcomes of ethnic minority households, including ownership of productive assets, longterm ownership of households and rice yield [25]. Kwame McKenzie (2018) studied on improving mental health care for ethnic minorities. The paper argued that multicultural society presents significant challenges to mental health services for ethnic minorities. Different ethnic groups have different disease rates, disease patterns, and ideas about appropriate care [26]. A study of ethnic minorities in Vietnam (2019) showed that although different ethnic groups have different cultural traditions, forests are still a major feature for many people. Ethnic minorities such as the Mong, Thai, Red Dao, Van Kieu, Ja Rai, E De and $\mathrm{Ba} \mathrm{Na}$ that live in different provinces across Vietnam all participate in community forestry activities. They used to have sacred forests used for worship, just as the majority of the Kinh used temples and family altars. Customary laws govern the areas of the forest where people take water and where the spirits of water are worshiped. Different customary laws govern different forest areas to produce forest products, such as medicinal plants, firewood and materials for handicrafts [27].

In recent years, there have been a number of studies of Vietnamese authors on socioeconomic issues of the Northwest region. Some of the following studies may be listed: The author Dang Nghiem Van (1982) analyzed the traditional socio-economic characteristics of ethnic minorities in mountainous areas. The author has analyzed the nature of the traditional economy, ownership issues, farming methods ... [28].The author Diep Dinh Hoa (1976) analyzed the types of farming on mountain slopes with the meaning of conquering the mountainous areas of the ethnic minorities of our country, the relationship of these economic types with agricultural tools, with the advent of agriculture ... [7, 8]. The author Trinh Ba Thao (1986) learned about the results of the implementation of policies on sedentarization and settlement in ethnic minority areas of our country in recent years [13].Author Nguyen Van Khanh (1983) analyzed the ruling policies of French colonialism 
for the Northwest ethnic minorities. In order to rule well, they used the obscurantism, maintained backward customs and social evils [10].The authors Vuong Xuan Tinh and Bui Minh Dao (2003) analyzed the issue of traditional land tenure by ethnic minorities in our country and the transformation of this issue today [4].The author La Van Lo (1981) learned about the traditional production experiences of ethnic minorities [11].The author thinks that this is a valuable field of local knowledge that needs to be preserved and promoted. The authors Be Viet Dang, Chu Thai Son and Ngo Duc Thinh (1987) studied the socioeconomic issues of northern mountainous provinces, achievements and problems raised need to be addressed today [5].The author Ha Que Lam (2002) studied the status of the implementation of poverty reduction policy in ethnic minority areas of our country, and proposed some solutions to implement this policy today. The author Khong Dien (1996) has built a fairly vivid and rich picture of the natural, environmental, socio-economic and social conditions of the Northern mountainous ethnic groups [2].In 1993, the Government Office organized a scientific conference on issues to be given priority to develop the commodity production economy in mountainous areas and ethnic minority areas of our country. The authors Jean Castella and Dang Dinh Quang (2002) studied land use changes and production strategies of farmers in Bac Can province. The author Tran Binh (2001) studied the economic practices of some ethnic groups in the Northwest of Vietnam [1].The author Cam Trong (1998) studied the ancient socio-economic history of the Thai people in the Northwest of Vietnam. The author Dang Thanh Nga (2003) learned about the weaving of Thai people in the Northwest in the current conditions. Author Cam Van Doan (1994) studied the household economic model in Son La and proposed some recommendations on the issues to be addressed [6]. The author Lam Mai Lan (2000) studied the socio-economic impacts on tourism activities in Sa Pa [12]. The author Trinh Thi Anh Hoa (2013) studied the accessibility of educational services of the poor in the Northern mountainous provinces in the context of educational socialization in Vietnam [9]. It can be said that the studies of Vietnamese authors on the production activities of the above-mentioned Northwestern ethnic groups are mainly from ethnological and economic perspective, there are no studies from the psychological perspective on production activities of the Northwestern ethnic minorities. This is the gap that this article wants to analyze.

\section{Research Methodology}

\subsection{Research sample}

a. Survey using questionnaires (quantitative survey):

Total number of people surveyed: 1,252 people

b. In-depth interview (qualitative survey):

Total number of people surveyed: 200 people

Total number of objects surveyed over the whole sample: 1,452 people

The survey was conducted in 11 communes and towns in 7 districts of 7 provinces of the Northwest: Dien Bien, Son La, Hoa Binh, Lai Chau, Lao Cai and Ha Giang. Survey locations are as follows:

Table 1: Survey locations

\begin{tabular}{|l|l|l|l|}
\hline No. & Provinces & Districts & Communes and towns \\
\hline 1 & Hoa Binh & 1.Kim Boi & 1. Tu Son \\
\hline 2 & & & \\
\hline 3 & Son La & 2.Muong La & 2. It Ong Town \\
\cline { 4 - 4 } & & & 3. Hua TraiCommune \\
\cline { 4 - 4 } & Dien Bien & $3 . T u a n$ Giao & 4. Phu NhungCommune \\
\cline { 3 - 4 } & & & 5. Quai NuaCommune \\
\hline
\end{tabular}




\begin{tabular}{|l|l|l|l|}
\hline 4. & Lai Chau & 4.Than Uyen & 6. Than ThuocCommune \\
\hline 5 & Lao Cai & 5. Bao Yen & 7. Long KhanhCommune \\
\cline { 4 - 4 } & & & 8. Viet Tien Commune \\
\hline 6 & Yen Bai & 6. Van Chan & 9. Nam Lanh Commune \\
\cline { 4 - 4 } & & & 10. Dong Khe Commune \\
\hline 7 & Ha Giang & 7. Vi Xuyen & 11. Viet Lam Town \\
\hline Total & $\mathbf{7}$ provinces & $\mathbf{7}$ districts & $\mathbf{1 1}$ communes and towns \\
\hline
\end{tabular}

The survey was conducted for 6 ethnic minorities, namely Thai, Muong, H'mong, Tay, Dao, Nung. These are the most populous ethnic groups in the Northwest. These are also the ethnic groups that the in-depth interviews are conducted over.

Table 2. Ethnic groups surveyed.

\begin{tabular}{|l|l|l|l|}
\hline No. & Ethnic groups & Total people surveyed & \% \\
\hline 1 & Thai & 223 & 17.9 \\
\hline 2 & Muong & 218 & 17.4 \\
\hline 3 & H'mong & 207 & 16.5 \\
\hline 4 & Tay & 218 & 17.4 \\
\hline 5 & Dao & 219 & 17.5 \\
\hline 6 & Nung & 165 & 13.1 \\
\hline & Invalid responds & 2 & 0.2 \\
\hline & Total & $\mathbf{1 , 2 5 2}$ & $\mathbf{1 0 0 . 0}$ \\
\hline & & & \\
\hline
\end{tabular}

The majority of the participants surveyed were male. The objects aged from 30 to 48 accounted for the highest proportion $(56.5 \%)$, followed by the objects aged below 29 years old. The objects with primary and secondary education accounted for the majority with $91.7 \%$, of which secondary education accounted for $51.6 \%$.

Table 3. Demographic characteristics of the ethnic groups surveyed.

\begin{tabular}{|c|c|c|c|c|}
\hline No. & Criteria & Specific criteria & $\begin{array}{l}\text { Number } \\
\text { (people) }\end{array}$ & $\%$ \\
\hline \multirow[t]{2}{*}{1} & \multirow[t]{2}{*}{ Sex } & 1.Male & 772 & 61.7 \\
\hline & & 2. Female & 480 & 38.3 \\
\hline \multirow{4}{*}{2} & \multirow{4}{*}{ Age } & 1.Under 29 years old & 288 & 23.0 \\
\hline & & 2. From $30-48$ years old & 707 & 56.5 \\
\hline & & 3. Over 49 years old & 247 & 19.7 \\
\hline & & Invalid responds & 10 & 0.8 \\
\hline \multirow{5}{*}{3} & \multirow{5}{*}{ Education } & $\begin{array}{l}\text { 1.Can speak Vietnamese, but cannot } \\
\text { read or write }\end{array}$ & 26 & 2.0 \\
\hline & & 2. Primary education & 503 & 40.1 \\
\hline & & 3. Secondary education & 647 & 51.6 \\
\hline & & 4. High school education & 71 & 5,6 \\
\hline & & Invalid responds & 5 & 0,4 \\
\hline 4 & Total & & 1.252 & 100,0 \\
\hline
\end{tabular}


The main research methods is to survey using questionnaires and in-depth interviews, mathematical statistics. One type of questionnaires has been designed for ethnic minorities. The content of the questionnaire focuses on the following psychological aspects of ethnic minorities: Awareness, production organization capacity, personality, communication, perception, attitudes and cultural continuity of ethnic minorities.

\section{Research results and discussion}

\subsection{Production methods of ethnic minorities}

The production organization capacity of ethnic minorities is firstly shown in the cultivation method, followed by the breeding method and the forest exploitation and afforestation method.

\subsubsection{About the cultivation methods of ethnic minorities}

For the ethnic minorities in the Northwest, agricultural production is the main occupation. In particular, the main activity is growing rice, farm produce and some other economically valuable plants with a decisive role in their lives. Depending on each ethnic group, locality, farming practices, the production methods of the ethnic groups have many similarities and differences. There are two main types of production of ethnic minorities: wet rice fields and upland fields. The survey results on this issue are as follows.

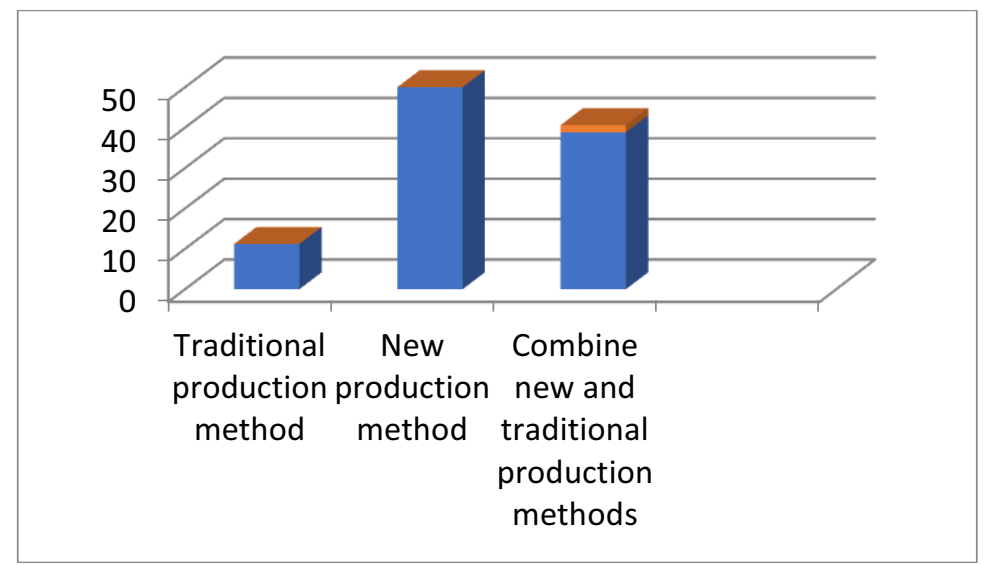

Fig.1. Production methods of ethnic minorities.

Analyzing chart 1, we find that ethnic minority families surveyed in 7 northwestern provinces producing in a new method accounts for the highest proportion (50\%); followed by families combining both traditional and modern production methods $(38.8 \%)$ and traditional production accounts for the lowest proportion $(11.2 \%)$. The ethnic minority families produce in a new method as wet rice cultivation. In production, families apply scientific and technological advances in breeding, caring and fertilizing, in harvesting products. The application of new production methods is mainly applied in lowland ethnic groups such as Tay, Nung, Muong and Thai. Because in the lowland areas, flat fields have favorable conditions for the application of machines in production and for irrigation and care.

Families combining both production methods are ethnic minority families living in the 
middle region, where both flat rice fields and terraced fields are available. In the terraced fields or mountain fields, ethnic minorities produce traditionally.

Ethnic minority families traditionally produce using autarky method. This production method is mainly used for cultivation on upland fields on rocky mountains and hilly land, which is difficult to plow.

The survey results of 2,028 households of the Institute of Ethnology in Son La province show that the majority of households still live mainly on agriculture with two parts: farming and shifting cultivation. $77.52 \%$ of households live on agriculture, only $1.53 \%$ on services and trading [3].

It is worth mentioning that agricultural production of ethnic minorities is facing great difficulties, first of all, low productivity. On average, the harvest is $25-26$ quintals/ 1 ha of wet rice fields, while for upland fields, the productivity is 11 - 15 quintals/ 1ha.The harvested rice is not enough for the people to use, so the meal still has to be padded with cassava. Other types of food such as maize, sweet potato, and cassava also produce low productivity, so the majority of ethnic minority families, mainly upland farming families, still suffer from hunger during the between-crop period.

Another difficulty of ethnic minorities in agricultural production is the lack of arable land. This situation is common in both farming and shifting cultivation. According to the survey data of 12 communes in Son La Province (Institute of Ethnology, 1999) [3], the average area of water field is $300 \mathrm{~m} 2$, the area of upland rice is $600 \mathrm{~m} 2$ and the area of cassava is $800 \mathrm{~m} 2$.Lai Chau has the same area. Now this area of production is decreasing due to population growth and free migration. When asked about production land, $79.4 \%$ of people said that they lacked cultivation land, $20.6 \%$ of them thought that it is enough and only $0.14 \%$ thought that it is surplus of arable land. For those who work on the mountain fields, $46.31 \%$ of them said that they lacked arable land; $53.39 \%$ of them think that it is enough and $0.32 \%$ thought that it is surplus of arable land.

The cause of the shortage of arable land is due to the rapidly increasing population, the severe destruction of the forest makes the soil degraded and washed away at a high rate. In order to have productive land, the people carried out the agricultural encroachment, expanding their farming scope outside the commune and district and even to neighboring provinces. For example, Thai people and La Ha people in It Ong commune and Nam Gion commune in Muong La district have crossed Da river to work in Liep Te commune (Thuy Chau district).The Thai people in Muong Chien and $\mathrm{Ca}$ Nang villages in $\mathrm{Ca}$ Nang commune, Quynh Nhai district have turned upstream 25-30 km from Da River to farm in Sin Ho and Tua Chua districts (Lai Chau province).Agricultural encroachment tends to increase, causing forest area to be narrowed, bare land and bare hills to increase.

Table 4.Current farming methods of ethnic minority families (By ethnic group).

\begin{tabular}{|c|c|c|c|c|c|c|c|c|}
\hline \multirow{2}{*}{ No. } & Farming methods & \multicolumn{6}{|c|}{ Ethnic groups(\%) } & \multirow{2}{*}{ Total } \\
\cline { 3 - 8 } & Bhai & Muong & H'mong & Tay & Dao & Nung & $\mathbf{1 1 . 2}$ \\
\hline 1 & By traditional method & 13.2 & 7.6 & 18.2 & 14.8 & 5.5 & 8.1 & $\mathbf{5}$ \\
\hline 2 & $\begin{array}{c}\text { By the new method, there } \\
\text { is the guidance of agricultural } \\
\text { extension staff }\end{array}$ & 54.8 & 65.2 & 38.5 & 59.2 & 50.3 & 65.3 & $\mathbf{5 0 . 0}$ \\
\hline 3 & $\begin{array}{c}\text { Combining both } \\
\text { traditional and modern }\end{array}$ & 32.0 & 27.3 & 43.3 & 26.0 & 44.2 & 26.6 & $\mathbf{3 8 . 8}$ \\
\hline
\end{tabular}

If comparing by the ethnic minorities surveyed, there are some noticeable points found:

Cultivation - the main activity in production of ethnic minorities, the traditional cultivation of H'mong ethnic group accounts for a higher proportion than other ethnic groups $(18.2 \%)$, meanwhile, cultivation in a new method with the guidance of agricultural extension staff of the H'mong people is the lowest and much lower than the remaining 5 
ethnic groups (38.5\%).

Cultivation in a new method with the guidance of agricultural extension staff of the Nung and the Muong is higher than that of the remaining ethnic groups $(65.3 \%$ and $65.2 \%)$.

Cultivation in the combination of both traditional and modern methods, the Dao and H'mong ethnic groups are the highest, higher than the remaining 4 ethnic groups.

Why is the rate of production in the traditional way of the H'mong people the highest? The results of document research and field surveys show that the H'mong people mainly live in upland areas, so the they have little water fields, but mainly shifting cultivation. The upland fields of the H'mong are divided into two types: settled upland fields (terrestrial cultivation) and nomadic farming upland fields, mainly nomadic farming upland fields. The H'mong have developed terraced fields on mountain slopes for a long time. Terraced fields are often plowed, harrowed, fertilized and weeded two to three times per crop. The selection of rice varieties is mainly empirical, but sometimes the H'mong families have selected good rice varieties suitable to local conditions.

In relatively flat places without condition to be turned into terraced fields, H'mong families turn into farm upland fields for long-term cultivation. For this type of upland fields, they plant food crops (maize) in the summer crop, and farm produces or specialty trees in the winter-spring crop. Crop yields here are relatively stable and high. Due to the limited number of farm land fields, the H'mong people often do nomadic farming fields, only planting 2-3 crops. The selection of land is usually done before Lunar New Year according to traditional experiences and is marked according to common conventions. After that, the upland fields are burned off in December or January, February and burned off and cleared in March to prepare for cultivation.

The upland fields of H'mong people have a high slope and are mostly cultivated.The Hmong plow can plow depth from 0.15 to $0.2 \mathrm{~m}$. The upland fields are plowed before the Lunar New Year and raked many times. Maize is cultivated on upland fields in March and April of the solar calendar with basal fertilizing. Legumes are usually grown in the middle of the maize holes. Assorted squash or green vegetables can be intercropped on the rice fields.

Nomadic farming shifting cultivation depends heavily on nature, crop yields are unstable and it only lasts a few years. Therefore, setting forest on fire for upland fields and shifting cultivation have become the common H'mong custom. The H'mong people often say that "where the fire is, the H'mong people go there" or "The H'mong people follow the upland fields". Production on the upland fields is very hard work, the working day can be up to 10 hours / day and people have to stay on the upland fields for a long time.

Why do the Tay and Nung people cultivate in a new method with the guidance of agricultural extension staff more than other ethnic groups?

This can be explained as follows:

Tay people have a fairly developed traditional agriculture. Their production is very close to that of the Kinh people (the majority).In the areas of Tay people, there are most crops in the Northern of Vietnam. Rice and maize are all grown in different areas and in different seasons. The diversity of crops has shown the production experience of the Tay people.

The Tay people's soil preparation technique is quite good. The Tay people's production toolkit includes many types, quite complete. The Tay's plow can plow depth from 0.15 to $0.20 \mathrm{~m}$. The Tay people use double rake, so the land working is easy and fast. There are many types of hoes: edge carving hoe, maize weeding hoe, land hoe, tree root dig hoe, grass rake are commonly used. People use sickles and scythes to harvest rice. In the past, in deep and water-ready fields, people often cultivated two crops (winter and winter-spring crops), in shallow fields, they took advantage of spring maize or wheat. After the harvest is completed, they grew sweet potatoes, potatoes and legumes. 
The Tay people's planting season is quite strict, mainly based on lunar periods, but also based on natural phenomena. The rice transplantation of summer crop is usually done before Tet, and the spring rice transplantation must be done in March. Winter crop is the main crop, so that it must be ensured the right time, the transplantation must be done in May. When the bombax ceiba is blooming, it is warm, maize can be planted.

The practice of basal fertilizing by Tay people is quite common. Previously, during the harvest time, the Tay people often helped each other to bring manure into the fields, one after another. They apply additional fertilizer to bad fields and weed. Weeding is usually done twice a crop.

Upland fields occupy an important position in the Tay's food production. The people work on hill fields to grow maize, cassava, legumes, sweet potatoes, sesame, peanuts, sugarcane and cotton. Maize is usually grown in two crops. Cassava occupies a significant area. The people have a lot of experience in intercropping and crop overlaping on soil types.

The Tay people's irrigation system is quite complete, so the two-crop fields increased. The application of scientific and technological advances of the Tay people is quite good and capable of doing many business activities, so the production efficiency is relatively high. Each Tay family often has a small garden right next to the house to grow vegetables, beans, sugarcane, fruit trees ...The Tay people have known how to grow fruit trees and industrial trees for a long time and it gives them a not-small profit. It can be said that the production method of the Tay people is more advanced and effective than that of the Northwestern ethnic groups.

Nung people are agricultural residents, they cultivate the water field proficiently similar to the Kinh people (the ethnic majority group in Vietnam).Due to their living conditions, in addition to farming on wet fields, they also practice shifting cultivation.

Like other ethnic minorities, the Nung farming techniques are rudimentary and outdated. Due to their experience, it is not difficult for them to choose forest and upland fields. Where there are old forests, large trees and overgrown schizostachyum aciculare are often chosen for clearing trees for cultivation. On the upland fields, sticky rice is grown mainly. Previously, they mainly used the autarky method, nowadays they often plant them by spreading seeds. After one month of cultivating, they weed. In the upland fields of rice, people see mustard greens, melons, gourds, squash and beans. This type of upland field is usually cultivated for several crops, they will leave when the soil is inferior. The cultivation can only be repeated 10 to 15 years after the forest regenerates and soil fertility increases.

For farming upland fields, the farming technique is not much different from ricegrowing. The people use plowing, pulling power of cattle, fertilizing. The main source of manure is animal manure, which is from cattle, horses, pigs and chickens. The plants grown on the farming upland fields are mainly maize, buckwheat and millet. The method of planting maize of the Nung people is similar to that of the Tay people and other ethnic groups. Before planting, the soil is plowed, harrowed, made for beds, and fertilized with manure or urine. People also grow maize and millet on the rocky slopes. That is the type of rocky cultivation. Vegetables such as mustard greens, kohlrabi, cabbage, onions, pickled small leeks ... are grown in small gardens next to the house or in the upland fields to provide food for the family. The Nung people know how to intensify and overlap their crops to not let the land rest. To make the soil fertile, people increase fertilizer. It can be said that, like the Tay people, the Nung people have a good agricultural farming method compared to other ethnic minorities.

Why are farming activities in combination of both traditional and modern methods of the Dao and H'mong people the highest?

The Dao people live mainly on agriculture. But for Dao people, the main form of production is nomadic farming. Terraced fields and water fields only account for a very 
small percentage. The Dao people live in all three regions, the middle and the low. In each region, the Dao people have different types of farming.

The middle region is the main residence area of the Dao people. Here Dao people practice nomadic farming. After cultivating a few crops, they will have to move to another place. This farming method is outdated, people cut the forests indiscriminately, leading to environmental destruction and causing great consequences. The production tools of the Dao are very primitive. People only need an ax, a knife, a stick, a scraper and a scythe.

For fields in the high rocky mountains: The Dao people in this region have already settled agriculture and house or rotated crops - settled house. They grow on narrow fields with many jagged rocks. This type of upland fields is called farm rocky fields, mainly for growing maize, besides, they can plant millet, sorghum or buckwheat. Production tools are as simple as in the middle area. The soil is less fertilized, erodes quickly, resulting in low crop productivity. The Dao people in this area often go hungry for a few months.

For upland fields in low areas, The Dao people often live in narrow valleys or along highways alongside the Tay, Nung or Kinh people. Water fields and terraced fields are the main types of cultivation in this region, in addition to settled upland fields. The Dao people in this region have the same farming method as the peoples around them. Farming tools include "chia voi" plow, wooden teeth or iron teeth rake, pulling power of cattle. For this type of upland field, the Dao people have applied scientific and technological advances, with more guidance from agricultural extension staff.

The Dao people start their farming from January to April in the lunar calendar. Old and dense forests with many big trees and near the water are the best cultivation places. The soil here has a lot of humus, plus the ash of the burning tree so it is very good. They burn trees after 20 to 30 days from the time of cutting the trees as there will be more ash if they burn dry trees. After burning, the cold ash is evenly leveled on the field for autarky. When sowing, they often work in pair: a male and a female. The male goes ahead and use a stick to prick holes by row, the distance between holes is about $20-30 \mathrm{~cm}$. The female will follow the male and carry a basket of seeds weighing about 2-3 $\mathrm{kg}$ behind her back, alternately put from 20 to 30 paddy grains in each hole and then fill it with soil. Along with autarky, people also use the method of spreading seeds. For spreading seeds, soil needs to be more carefully prepared. The Dao people have known how to use intercropping techniques for a long time. There are few fields with only one crop plant. Besides the main crop plants, there are several other plants. They are usually maize or beans in addition to rice. On the upland fields, it is possible to grow vegetables such as mustard greens, melons, cucurbits ... Some places, people grow crops of high economic value such as tea, tung, bodhi, anise ...

H'mong people also do farming by combining the traditional method (autarky)and new production method (using new seeds, chemical fertilizers, pesticides, guidance of agricultural extension staff). H'mong families apply a new production method in areas where there are farm land fields and wet rice fields, and they apply traditional cultivation of autarky, shifting cultivation, and nomadic farming on slopes of mountains.

Thai people is an ethnic group organizing their farming activities under the guidance of agricultural extension staff or quite high combination of traditional and modern farming. The Thai people have many initiatives and experience in building an irrigation system appropriate to the terrain. The Thai knew how to use plows and pulling power (cattle) in cultivation for a long time. Before the August Revolution in 1945, in some places, the Thai people had not use the plow. They use the "hoả canh thuỷ nậu" method i.e. burning straw and grass in the field and letting water in, then letting the buffalo to trample or rake, without plowing, then transplanting rice. This method is suitable for some mountainous fields, because the soil here is porous and thin, if they plow too deep, the soil can be damaged. On the other hand, this method is suitable for the condition that people still do 
not use fertilizer. Later, the use of fertilizers such as muck, night soil, green manure, chemical fertilizers has created a great change in the production method of the Thai people.

Previously, the rice sowing and making of Thai people also had their own characteristics. People often soak rice seeds in warm water and mix with 1 gram of salt every $20 \mathrm{~kg}$. When the rice germinates, sow them in rice-seedling field. When the rice seedlings are $20-25 \mathrm{~cm}$ tall, pull up and transplant thickly into another field and when rice seedlings are strong, pull up and transplant into the fields. According to their conception, doing so, the rice plants will be healthy and grow fast.

Previously, Thai people transplanted only one crop, rarely two crops. Currently, two crops have become popular and people use new rice varieties so the yield is quite high. Upland fields play an important role for Thai people, in some places the people do not have water fields but only live on the upland fields. Upland fields provide people with a certain amount of food such as rice, maize, sweet potatoes, cassava ... and some foodstuff like gourds, peanuts, sesame, green vegetables, cotton for clothes, blankets. Today, the Thai people's farming practices have changed a lot. They know how to use machines like water pumps, people in some places use plows and harrows. People know how to use pesticides, chemical fertilizers, muck, increase crop production ... Therefore, the living standards of the people have been significantly improved.

The Muong people is an ethnic group with the lowest traditional production method (7.6\%) and the highest new production method (65.2\%) compared to the ethnic minorities surveyed. The Muong people have been cultivating for a long time and live permanently. Farming occupies a leading position of this ethnic group, for Muong people, rice is the main food crop. Glutinous rice is grown more than ordinary rice. Before the revolution, Muong people often monoculture rice and rarely grow other crops. Muong people grow rice quite a lot on terraced fields, many narrow fields can only be hoed without plowing. Previously, Muong people transplanted only one crop, few places transplanted two crops. The places with two crops are adjacent to the plains where the fields are relatively low.

Cultivation techniques of Muong people are still quite low. After harvesting, people often plow for the first time and prepare for the next crop. In some places, buffaloes trample the fields to kill grass and make the soil fine, then harrow and transplant. Labor tools such as plowing and harrowing of Muong people are still rudimentary. Plow is mainly of "chia voi" plow, harrow with small teeth made of bamboo or wood, less iron harrow. Muong people rarely rake the grass, but mainly weed by hand. After a month or more from transplanting, they weed and usually only once in a crop.

In production, Muong people have a lot of experience in small irrigation. People often make ditches to get water. This job requires many people, so sometimes the whole village and the whole hamlet is mobilized. Stream water must be stopped, flowing along ditches leading to high fields. From high fields, water flows down to the lower fields. Along the ditches, for fields that need water, people make grooves or use bamboo and neohouzeaua bamboo tubes to form small streams to guide water into the fields. In some places such as Phu Tho and Hoa Binh, people use water wheels to lead water into the fields. Water wheels can bring water to a height of $5-6 \mathrm{~m}$. Although water is collected all day and night, the amount of water is small and the area irrigated is not large.

Upland fields also plays an important role in production of Muong people. Although the upland field area is not much, every family own it. On upland fields, the people cultivate crops and other trees such as "luồng" and "trẩu sở". In some areas, people grow thorns, jute, cinnamon, medicinal plants, cotton ...It can be said that before the August Revolution in 1945, the production of Muong people was self-sufficient, mainly agriculture. Today, Muong people's farming has changed a lot, families know how to apply scientific and technological advances to production. Due to reclamation and increased crops, the rice growing area of Muong people is increasingly expanding. If previously the Muong people 
mainly cultivated rice, now their area of crops increased, the area of planting industrial crops also increased. Scientific and technical advances have been applied in production such as new breeds, chemical fertilizers, pesticides, seasonal planting.

It is worth mentioning that through our observation and practice, the traditional production methods of ethnic minorities have basically been maintained. The method of shifting cultivation, habits, experiences has not changed much. There is a clear change that we can see that many families know how to apply chemical fertilizers and use new varieties. However, the narrow terrain, terraced fields, hills, difficult transportation, lack of production capital, limited education... have made it difficult for ethnic groups to change their production methods.

\subsubsection{Breeding methods of ethnic minorities}

The breeding plays a huge role in the lives of the Northwest ethnic minorities. The breeding of ethnic groups depends on the cultivation. The families raise the cattle to gain the traction forces, carry the goods, use as transport vehicles and eat their meat. The most cattle types are pigs, chickens, ducks, swans and geese.

The cause of breeding is not separated from the cultivation partly because of climate, tropical monsoon weather, low humidity and many diseases, therefore, no family dares to live on the breeding only. In the research contents of the title, we have investigated whether the breeding methods of people has changed. The survey results are shown in the following table.

Table 5. Current breeding methods of ethnic minority families.

\begin{tabular}{|c|c|c|c|c|c|c|c|c|}
\hline \multirow{2}{*}{ No } & \multirow{2}{*}{$\begin{array}{l}\text { Breeding } \\
\text { method }\end{array}$} & \multicolumn{6}{|c|}{ Ethnic group (\%) } & \multirow{2}{*}{ Overall } \\
\hline & & Thai & Muong & H'Mong & Tay & Dao & Nung & \\
\hline 1 & \begin{tabular}{l}
\multicolumn{1}{c}{ By } \\
tradditional \\
method
\end{tabular} & 54.7 & 42.4 & 57.3 & 21.1 & 23.9 & 13.2 & 35.4 \\
\hline 2 & $\begin{array}{l}\text { Applicati } \\
\text { on of } \\
\text { advanced } \\
\text { science - } \\
\text { technology }\end{array}$ & 22.9 & 35.9 & 19.5 & 29.9 & 38.1 & 49.6 & 32.6 \\
\hline 3 & Both & 22.4 & 21.7 & 23.2 & 48.1 & 38.1 & 37.2 & 22 \\
\hline
\end{tabular}

The analysis of the data in Table 5 shows that: The number of surveyed ethnic minority households say that they still bread according to traditional experiences, accounting for a high proportion (35.4\%). Compared to the above production method, this ratio is much higher $(35.4 \%$ compared to $11.2 \%)$. That is, the breeding in the traditional way is higher than cultivating in the traditional way. Only over $50 \%$ say they have applied the scientific and technological advances to the breeding or a combination of traditional and modern breeding.

The breeding is now the second most important production sector after the cultivation of the ethnic minorities. In recent years, the Government has paid attention to the breeding, which has been focused and developed. According to the survey data of 12 communes of Son La of the Institute of Anthropology (1999), the current buffalo population is 8,245, with an average of 1.1 units per household. If counting the cows, each household has 1.6 units. On average, each household has 2.3 pigs and 17.2 chickens and ducks [3]. Horses play an important role in transporting the goods of ethnic minorities when the traffic system is limited. But, the horses have been focused on development. There are only 115 horses in 12 communes of Son La. The goats are raised under the hunger eradication \& poverty 
reduction program and now develop relatively well, with 4,573units in 12 surveyed communes.

The breeding in the tradditional way of the ethnic groups is a form of free-grazing in the forests and around their houses. Many families have a herd of tens of cattle or even hundreds of cattle grazing in the forests. But this grazing is limited due to the theft of cattle and the cattle which clear the fields. In addition, the pigs, chickens, and geese ... are grazed around the houses. They defile, pollute the environment. However, there are still many families grazing like that.

It can be said that breeding of ethnic minorities is still self-sufficient and not yet commercial. They breed mainly for getting the pulling forces, carrying the goods, getting the timber and for public holidays and Tet holidays, when the families have big events (house building, wedding, funeral, death anniversary ...). The raising of cattle into a farm becomes a major job and is separated from the cultivation and characterized by the goods, which has not been clearly shown. In some places, the breeding products have not had markets for consumption, with the prices reduced by the traders, the epidemics often occur yearly, cold periods cause great losses for ethnic minority families. In some places, food for cattle and poultry is not enough, cows and buffaloes are grazed, and the crops are destroyed, therefore, there are regulations in the locality that restrict the breeding.

\subsubsection{Methods of forest exploitation and afforestation}

The forest plays an important role for the ethnic minorities. The forest is not only a store of materials for building the houses, tools and household tools, but also an important source of food for the ethnic minorities. That is also the cause of persistent existence of appropriated economic forms. The gathering provides the ethnic groups with foood in the poor food periods. Fishing on rivers and streams is quite developed. Most of families have the fishing instruments. Hunting and trapping also quite diverse and develop among the ethnic groups.

As analyzed above, due to shifting cultivation, nomadic farming, shifting cultivation, timber for house construction, sales, etc., in recent years, the forest has been severely destroyed. Each year, up to 30,000 hectares of forest are destroyed, causing environmental pollution and serious consequences. The survey results on forest exploitation methods of ethnic groups are shown in the following table:

Table 6. Current forest exploitation methods of ethnic minority families.

\begin{tabular}{|c|c|c|c|c|c|c|c|c|}
\hline No & $\begin{array}{c}\text { Forest } \\
\text { exploitation } \\
\text { method }\end{array}$ & Thai & Muong & H'mong & Tay & Dao & Nung & Total \\
\cline { 3 - 8 } 1 & $\begin{array}{c}\text { By tradditional } \\
\text { method }\end{array}$ & 37.3 & 47.3 & 52.4 & 12.1 & 19.1 & 15.1 & $\mathbf{3 0 . 5}$ \\
\hline 2 & $\begin{array}{c}\text { Application of } \\
\text { advanced } \\
\text { science }- \\
\text { technology }\end{array}$ & 54.2 & 36.5 & 41.7 & 5.6 & 42.6 & 56.6 & $\mathbf{4 7 . 8}$ \\
\hline 3 & Both & 8.5 & 16.2 & 5.8 & 32.3 & 38.2 & 28.3 & $\mathbf{2 1 . 7}$ \\
\hline
\end{tabular}

The survey data in Table 6 shows that: Nearly half of the people surveyed said that they have exploited the forests according to instructions, applying the scientific and technical advances. It means that the forest is rationally exploited, ensuring the development of the forest. In recent years, due to the propaganda, education and implementation of a number of forest protection and development projects, the forest protection and afforestation have 
been made better. The area of mountains is greened up.

However, a significant proportion of the surveyed families think that they still exploit the forest in the traditional way. Here, the forests can be exploited in two directions: the forests are exploited in moderation to develop and secondly,the forests are heavily destroyed. Due to free migration, shifting cultivation, and nomadic life, the fact is that forests are still destroyed rather than conscious exploitation.

If comparing among the ethnic groups, the Hmong people exploit the forest in the most traditional way $(52.4 \%)$. In fact, among the free migrants, nomadic people, the Hmong ethnic group always accounts for the highest proportion. This also means that they are exploiting the forests more than other ethnic groups. When asked why they burned down the forest, they said "in the plain, Kinh people eat fishes in the sea and here, we eat trees in the forest". With such interpretation, in their awareness, the the arbitrary deforestation and exploitation is of course, there is nothing wrong at all.

\subsection{Purpose of agricultural production}

Studying the agricultural production purpose, we will better understand the production capacity of the ethnic minorities. As analyzed above, the traditional production of ethnic groups is a self-sufficient production method. The purpose of this production is to cultivate and breed mainly for daily life of the families. The question is: Has the production purpose of the ethnic groups currently changed? The results of investigations on this issue are mentioned below.

Table 7. Purpose of agricultural production of ethnic minorities.

\begin{tabular}{|c|c|c|c|c|}
\hline No & Purpose & Only for use \% & For use and sales \% & Mainly for sales \% \\
\hline 1 & Rice farming & 58.1 & 40.7 & 1.2 \\
\hline 2 & Vegetable farming & 80.4 & 19.2 & 0.5 \\
\hline 3 & Fruit trees & 53.8 & 33.5 & 12.6 \\
\hline 4 & Breeding & 23.9 & 55.2 & 21.0 \\
\hline 5 & Secondary jobs & 20.9 & 18.9 & 60.2 \\
\hline & Overall & $\mathbf{3 9 . 5}$ & $\mathbf{4 4 . 6}$ & $\mathbf{1 5 . 9}$ \\
\hline
\end{tabular}

The analysis of the data in Table 7 shows that: The number of opinions thought that the main purpose of production is to use accounting for a large proportion (nearly $40 \%$ ) of the respondents. As analyzed above, the ethnic minority families, whether cultivation or breeding, mainly serve their daily life. Among the cultivation fields, planting the vegetables is mainly used for the cultivation, following planting rice and fruit trees. The type of production with the highest commodity nature is secondary jobs. In some villages of the Northwest, due to getting the experience from Kinh people, many ethnic minority families know how to plant the industrial crops such as cardamom, oranges, tangerines, etc. to sell to the lowland provinces. Therefore, their standard of living has improved greatly.

The percentage of "mostly for sales" responses of the surveyed families accounts for the lowest level (19.5\%). Thus, the nature of commodity production is very low and production is still self-sufficient, clearly shown in the ethnic minorities.

Another important indicator reflecting the self-sufficiency of production among the ethnic minorities in the Northwest is the cost of production. Based on the results of the socio-economic baseline survey of ethnic groups conducted by the Institute of Anthropology in 1999, the cost of production of ethnic groups is very low. According to a survey of 2,038 households, the majority have production costs of less than VND 500,000 per year. 
Table 8. Production costs of ethnic minorities (average per household in a year).

\begin{tabular}{|c|c|c|c|}
\hline No & Cost (VND) & $\begin{array}{c}\text { Number of } \\
\text { households }\end{array}$ & Ratio (\%) \\
\hline 1 & Less than 500,000 & 1165 & 57.16 \\
\hline 2 & $500,000-1,000,000$ & 425 & 21.00 \\
\hline 3 & $1,000,000-2,000,000$ & 328 & 16.09 \\
\hline 4 & $2,000,000-5,000,000$ & 117 & 5.75 \\
\hline
\end{tabular}

It is worth noting that most of the cost is used to buy breeds and seeds (rice seeds, chickens, pigs ...), then to buy the agricultural tools. The costs of fertilizer and pesticides are negligible.

Over the years, with the support of the state, many ethnic minority families have changed their mindset and behavior in production. They have applied the scientific and technological advances in production and daily life. Due to the requirements of production and living in many regions, some households have generators, rice mills, animal feed mills, chainsaws, etc. According to preliminary statistics of 19 communes in Son La and Lai Chau provinces surveyed, there were 844 generators, 319 gasoline engines, 364 milling machines, 38 rice threshers, 12 cattle mills, and 6 sawing machines. The gasoline engines to attach to motor boats running on the Da River, generators are used as small hydroelectricity to run the water to light the families.

Another indicator reflecting the production capacity of ethnic minorities is the source of income of ethnic minorities. The survey results are shown in Table 8.

Table 9. Income sources of ethnic minorities.

\begin{tabular}{|c|c|c|c|c|c|c|c|}
\hline \multirow{2}{*}{ No } & \multirow{2}{*}{ Income source } & \multicolumn{7}{|c|}{ Ethnic group (\%) } \\
\cline { 3 - 8 } & Thai & Muong & H'mong & Tay & Dao & Nung \\
\hline 1 & Rice farming & 38.5 & 35.4 & 38.6 & 30.5 & 33.7 & 30.0 \\
\hline 2 & Breeding & 23.3 & 27.9 & 23.1 & 30.7 & 27.4 & 25.1 \\
\hline 3 & Forest exploitation & 2.4 & 3.3 & 4.7 & 4.2 & 7.7 & 6.4 \\
\hline 4 & Vegetables & 20.0 & 16.3 & 16.0 & 14.0 & 10.9 & 9.2 \\
\hline 5 & Fruit trees & 5.1 & 10.3 & 8.0 & 11.4 & 9.9 & 11.3 \\
\hline 6 & Services & 0.7 & 1.1 & 0.9 & 0.9 & 0.4 & 1.4 \\
\hline 7 & Secondary jobs & 0.9 & & 0.9 & 1.9 & 4.2 & 7.1 \\
\hline 8 & Sales & 1.3 & & 0.5 & 1.1 & 1.7 & 1.4 \\
\hline 9 & $\begin{array}{c}\text { Others (saving, } \\
\text { support from } \\
\text { others) }\end{array}$ & 7.9 & 5.7 & 7.3 & 5.3 & 4.1 & 8.0 \\
\hline
\end{tabular}

The data in Table 9 shows: The largest income source of the ethnic groups is from rice cultivation and breeding, of which rice cultivation occupies the top position. On average, the revenue from rice accounts for $34.4 \%$ and the income from the breeding accounts for $26.2 \%$. As analyzed above, rice cultivation of ethnic groups from farming and shifting cultivation, in which upland fields occupy an important position. With rudimentary farming techniques, limited fertilization (due to lack of capital, knowledge of limited fertilization techniques, lack of water ...), due to poor soil because of much forest destruction ... therefore, the productivity of rice cultivation is low. As for the breeding, we find it mainly to get the traction force, carry goods and meet the food needs to serve holidays, families have big events and daily activities. The commodity nature of the breeding is very lackluster.

If comparing among the surveyed ethnic minorities, we can see that the Tay and Nung 
people have better production efficiency when the ratio of income from breeding, fruit tree planting, and extra jobs is higher than other ethnic groups. It is worth noting that some sectors that are important for the development of the family economy according to the commodity orientation are activities such as: services, trading, extra jobs - occupations that have much higher efficiency than pure agricultural production still accounts for a very low proportion of the people's income. Revenue from services is $0.9 \%$, from trading is $1.2 \%$ and income from secondary industry is $3.0 \%$. This is a convincing evidence that reflects that the economy is still small and self-sufficient of the Northwest ethnic minorities, reflecting the limited production capacity of ethnic minorities.

\section{Conclusion}

Compared to the traditional production method, the current ways of cultivation, breeding and forest exploitation have changed remarkably. Most families know how to apply the scientific and technical advances to production or a combination of traditional and modern production methods. An effective model of commodity production for ethnic minority families has appeared in some localities, but due to the objective reasons of the complicated mountainous terrain that produced in a new way, the progress has encountered many difficulties, not achieving the desired results. It can be said that the production capacity of the ethnic minorities surveyed is quite limited. The production of ethnic groups is still selfsufficient. This is reflected in many criteria, firstly for all purpose of production, the cost of production.

Cultivation and breeding of families are mainly for use, the percentage for sale is very low. The production costs for families are low, mainly for seed, and very little for fertilizer and production tools. The production tools of ethnic groups are still mainly simple and traditional tools. The main income of people from rice cultivation and breeding, secondary jobs, trading and services contributes very little to the income structure of ethnic minority families. It can be said that the production of ethnic groups is still basically backward production, small, self-sufficient, the nature of commodity production has not been clearly shown.

\section{References}

1. B. Tran, Economic practices of some ethnic groups in Northwestern of Vietnam. Ethnic Culture Publishing House, Hanoi (2001)

2. D. Khong, Socio-economic characteristics of the Northern Mountains. Social Sciences Publishing House, Hanoi (1996)

3. D. Khong, Report on the results of the project "Basic economic, social and cultural surveys of ethnic groups in Vietnam", Hanoi (2001)

4. M. D. Bui, Some issues of poverty reduction among ethnic minorities in Vietnam. Social Sciences Publishing House, Hanoi (2003)

5. V. D. Be, T. S. Chu, D. T. Ngo, Some socio-economic issues in the Northern mountainous provinces. Social Science Publishing House, Hanoi (1987)

6. V. D. Cam Van Doan, Household economic model in Son La and problems to be solved, Ethnicity and Era No. 03. (1994)

7. D. H. Diep, Type of farming or form of conquering the hilly areas of our country, Journal of Ethnology, No. 1. (1976)

8. D. H. Diep, Hmong people and plant world, Ethnic Culture Publishing House, Hanoi (1998) 
9. T. A. H. Trinh, Final report of ministry level project: Assessment of access to educational services of the poor in the Northern provinces in the context of educational socialization in Vietnam. Code B 2011-37-04 (2013)

10. V. K. Nguyen, Overview of the ruling policies of the French colonialism for ethnic minorities in the Northern and Central Highlands provinces, Ethnography Journal, No. 3 (1983)

11. V. L. La, Some experiences in traditional production of mountainous people, Ethnographic Collection (1981)

12. M. L. Lam, Socio-economic impacts of tourism on ethnic minorities in Sapa, Journal of Ethnography, No. 4 (2000)

13. B. T. Trinh, Results of sedentary farming in ethnic minority areas, Ethnographic Journal, Issue 1 (1986)

14. Vietnam Population and Housing Census, Statistical Publishing House, Hanoi 2010.

15. A. M. Altay, Social Development at the Local Level and Developing Public Services: Defining a local policy of integration for ethnic minorities. International Sociology (1996)

16. T. Oc , S. Tiesdell, Supporting Ethnic Minority Business: A Review of Business Support for Ethnic Minorities in City Challenge Areas. (1999)

17. P. S. Li, Social capital and economic outcomes for immigrants and ethnic minorities. Journal of International Migration and Integration No. 05, 171-190 (2004)

18. A. R. J. Dainty, B. M. Bagilhole, K. H. Ansari, and J. Jackson, Creating equality in the construction industry: an agenda for change for women and ethnic minorities. Journal of Construction Research 5(1), 75-86 (2004).

19. R. Plant (2002), Indigenous peoples/ethnic minorities and poverty reduction regional report. Asian Development Bank Box 789, 0980, Manila, Philippines (2002)

20. M. G. Robert, A construct for building the capacity of community-based initiatives in racial and ethnic communities: a qualitative cross-case analysis. Journal of Public Health Management \& Practice 15(2), E1-E8 (2009)

21. D. Deakins, M. Majmudar \& A. Paddison. Developing success strategies for ethnic minorities in business: Evidence from Scotland. Journal of Ethnic and Migration Studies. 23(3), 325-342 (2010)

22. H. G. Vu, 2012 Vietnam poverty assessment : well begun, not yet done - Vietnam's remarkable progress on poverty reduction and the emerging challenges. (2012)

23. K. S. Imai, R. Gaiha \& W. Kang, Poverty, inequality and ethnic minorities in Vietnam. Journal International Review of Applied Economics 25(3), 249-282 (2011)

24. Q. T. Tran, Socio-Economic Determinants of Household Income among Ethnic Minorities in the North-West Mountains, Vietnam. Croatian Economic Survey 17(1), $139-159$ (2015)

25. V. C. Nguyen, D. T. Phung, Do the poorest ethnic minorities benefit from a large-scale poverty reduction program? Evidence from Vietnam. The Quarterly Review of Economics and Finance. Volume 56, 3 -14 (2015)

26. M. Kwame, Improving mental healthcare for ethnic minorities. Advances in Psychiatric Treatment, 14(4) 285-291 (2018)

27. Results of 2019 census on ethnic minority groups announced. Rights of Vietnamese ethnic minority people promoted. Open Development Initiative, An Est - West management Institute project. (2019) 
28. N. V. Dang. Traditional socio-economic characteristics of ethnic minorities in mountainous areas, Ethnographic Journal, No. 1 (1982) 